\title{
Methionine Aminopeptidase 2
}

National Cancer Institute

\section{Source}

National Cancer Institute. Methionine Aminopeptidase 2. NCI Thesaurus. Code C143021.

Methionine aminopeptidase $2(478 \mathrm{aa}, \sim 53 \mathrm{kDa}$ ) is encoded by the human MET AP2 gene. This protein plays a role in both the steric hindrance of phosphorylation of the alpha subunit of eukaryotic initiation factor 2 (EIF2S1) and the removal of the aminoterminal methionine from nascent proteins. 